\title{
Influence of Supercritical Carbon Dioxide Extraction Conditions on Extraction Yield and Composition of Nigella sativa L. Seed Oil-Modelling, Optimization and Extraction Kinetics regarding Fatty Acid and Thymoquinone Content
}

\author{
Grzegorz Gawron ${ }^{1}$, Wojciech Krzyczkowski ${ }^{2}$, Robert Łyżeń ${ }^{1}$, Leszek Kadziński ${ }^{1, *(D)}$ and Bogdan Banecki ${ }^{1}$ \\ 1 Intercollegiate Faculty of Biotechnology of University of Gdansk and Medical University of Gdansk, \\ University of Gdansk, Abrahama Str. 58, 80-307 Gdansk, Poland; grzegorz.gawron@phdstud.ug.edu.pl (G.G.); \\ robert.lyzen@biotech.ug.edu.pl (R.Ł.); bogdan.banecki@biotech.ug.edu.pl (B.B.) \\ 2 Biovico Sp. z o.o., Hutnicza Str. 15 B, 81-061 Gdynia, Poland; wojciech.krzyczkowski@biovico.pl \\ * Correspondence: leszek.kadzinski@biotech.ug.edu.pl
}

Citation: Gawron, G.; Krzyczkowski, W.; Łyżeń, R.; Kadziński, L.; Banecki, B. Influence of Supercritical Carbon Dioxide Extraction Conditions on Extraction Yield and Composition of Nigella sativa L. Seed Oil-Modelling, Optimization and Extraction Kinetics regarding Fatty Acid and Thymoquinone Content. Molecules 2021, 26, 6419. https://doi.org/ $10.3390 /$ molecules26216419

Academic Editor: Stefano Cardea

Received: 7 October 2021

Accepted: 22 October 2021

Published: 24 October 2021

Publisher's Note: MDPI stays neutral with regard to jurisdictional claims in published maps and institutional affiliations.

Copyright: (c) 2021 by the authors. Licensee MDPI, Basel, Switzerland. This article is an open access article distributed under the terms and conditions of the Creative Commons Attribution (CC BY) license (https:// creativecommons.org/licenses/by/ $4.0 /)$.

\begin{abstract}
Nigella sativa L. is cultivated in many regions and its seeds have found use in variety of foods, but also in traditional medicine due to high content of biologically active essential oils. In this work optimization of supercritical carbon dioxide extraction from $N$. sativa seeds was performed using response surface methodology to describe the influence of extraction conditions on oil yield. Kinetics of oil and thymoquinone extraction were analyzed as well. It was demonstrated that in order to collect thymoquinone-rich $N$. sativa oil fraction, appropriate for health-related applications, the extraction should be carried out at $40{ }^{\circ} \mathrm{C}$ and $10-15 \mathrm{MPa}$. Following application of higher pressure of $35 \mathrm{MPa}$ enables effective extraction of remaining oil rich in polyunsaturated fatty acids suitable for use in food industry. Thymoquinone-dependent antibacterial activity of the N. sativa seed oil was observed against bacterial pathogens: Haemophilus influenzae, Staphylococcus haemolyticus, Staphylococcus epidermidis, Enterococcus faecalis and Escherichia coli.
\end{abstract}

Keywords: Nigella sativa; thymoquinone; supercritical fluid extraction; response surface methodology; antibacterial activity

\section{Introduction}

Nigella sativa L. (NS), known as black cumin or black seed, belongs to Ranunculaceae family and is an annual herbaceous plant cultivated mainly in North-East Africa, Middle East, South-East Asia and also in some European countries. The nutritional value and characteristic taste of the NS seeds and seed oil make for their use as food ingredients in various cuisines as they constitute an abundant source of unsaturated fatty acids, essential oils, saponins, alkaloids, glycolipids, and fat-soluble vitamins [1-3]. Furthermore, the NS seeds are a rich source of biologically active compounds [4] and, in different forms, have been applied in traditional medicines of Middle and Far East to treat a vast variety of conditions, such as: hypertension, asthma, diabetes, inflammation, fever, kidney or liver disfunctions, cough, eczema or influenza [5-7]. The dominant contribution to the biological activity of NS seeds is attributed to thymoquinone (TQ) $[4,5,8,9]$. Some of its properties reported in recent studies are antioxidant [10,11], anti-inflammatory [7], anti-cancer [12,13], smooth muscle relaxant [14], antifungal [15] and antibacterial activity [16-19]. The chemical structure of thymoquinone is shown on Figure 1.

Various techniques have been implemented to extract biologically active compounds from plant material. Traditional methods include solvent extraction, Soxhlet extraction or steam distillation, while supercritical fluid extraction has been developed and applied in research as well as for industrial purposes more recently $[20,21]$. Supercritical fluids have density and solubility characteristic for a liquid, while the rate of diffusion, compressibility, 
viscosity and penetration rate are close to gases. This facilitates mass and heat transfer speed multiple times more efficient compared to the corresponding quantities for liquids, which results in a significant acceleration of the extraction processes. Supercritical $\mathrm{CO}_{2}$ is a Lewis base with proton-acceptor properties and polarity comparable to that of pentane or hexane This feature makes $\mathrm{scCO}_{2}$ an ideal candidate for extraction of essential oils which are mixture of non-polar, low-molecular compounds such as terpenes, aldehydes, ketones, alcohols, esters, phenols or lactones. The process takes place under anaerobic conditions, which protects the components against oxidation. $\mathrm{CO}_{2}$ is easily removed from the extract, it is non-flammable, non-corrosive, cheap, tasteless, colorless, inert and generally recognized as safe by Food and Drug Administration and European Food Safety Authority [22,23].

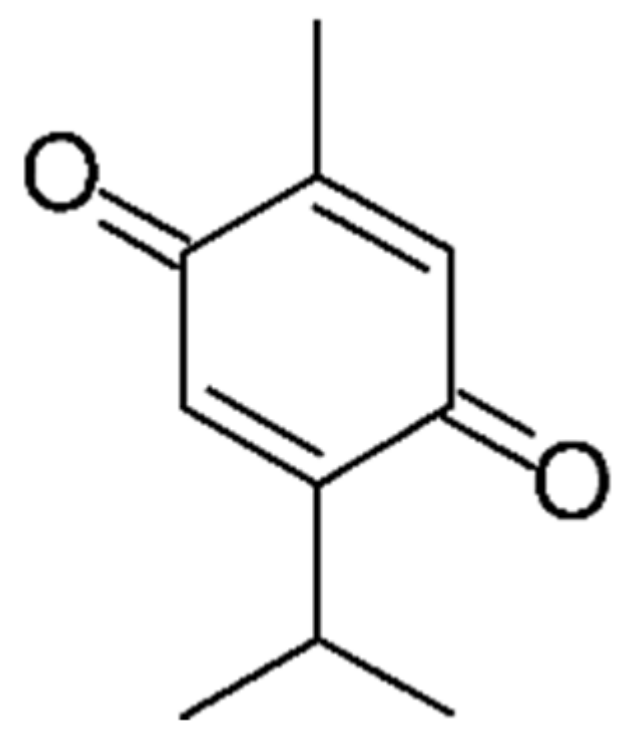

Figure 1. Chemical structure of thymoquinone.

Supercritical carbon dioxide has turned out to be an alternative, green, eco-friendly solvent. Changing operative pressure and temperature cause significant changes in the density of the solvent and therefore it is possible to control the extract composition without the need of extent organic solvents consumption [24].

This study was designed and performed to determine $\mathrm{scCO}_{2}$ extraction conditions suitable for extraction of desired fractions of NS seed oil suitable for different industrial applications. Firstly, the NS seed oil extraction yield dependencies on $\mathrm{scCO}_{2}$ extraction conditions, i.e., temperature, pressure, $\mathrm{scCO}_{2}$ flow and extraction time and the yield of extraction from NS seeds were studied. Subsequently, the kinetics of thymoquinone and oil extraction at selected conditions was examined. As there are only few reports on the optimization of oil extraction from NS seeds using $\mathrm{scCO}_{2}$, which describe the effects of various extraction conditions on NS oil yield in the available literature [25-27], determination and mathematical description of the relationship between the parameters of the extraction process and the oil yield as well as TQ content in the oil presented in this work provides valuable information for parties interested in processing of NS seeds for food and medicinal purposes. The antibacterial activity of the NS seed oils differing in TQ concentration were examined against reference strains of human pathogens causing infections of skin, gastrointestinal tract and respiratory system: Haemophilus influenzae, Staphylococcus haemolyticus, Staphylococcus epidermidis, Enterococcus faecalis, Escherichia coli, Shigella sonnei, Serratia odorifera and Salmonella typhimurium and compared to effects of commercially available antiseptics, i.e., chlorquinaldol or a composition of amylmetacresol and 2,4-dichlorobenzyl alcohol to assess the oils' potential as antibacterial agent. 


\section{Results}

2.1. Modelling of Oil Extraction from Nigella sativa Seeds

Supercritical $\mathrm{CO}_{2}$ extraction of NS seeds under different conditions of pressure, temperature, extraction time and $\mathrm{scCO}_{2}$ flow gave oil yield from $6.13 \%$ to $31.15 \%$ (Table 1 ).

Table 1. Experimental matrix and results in central composite rotatable design $2^{4}$ experiment; $X_{1}-$ pressure $(\mathrm{MPa}), X_{2}-$ temperature $\left({ }^{\circ} \mathrm{C}\right), X_{3}$-extraction time $(\mathrm{min}), X_{4}-\mathrm{scCO}_{2}$ flow $(\mathrm{mL} / \mathrm{min})$. Coded values of the variables are in parentheses.

\begin{tabular}{|c|c|c|c|c|c|c|}
\hline \multirow{2}{*}{ No } & \multirow{2}{*}{$\begin{array}{c}X_{1}, \text { Pressure } \\
(\mathrm{MPa})\end{array}$} & \multirow{2}{*}{$\begin{array}{c}X_{2}, \text { Temperature } \\
\left({ }^{\circ} \mathrm{C}\right)\end{array}$} & \multirow{2}{*}{$\begin{array}{l}X_{3,} \text { Time } \\
(\min )\end{array}$} & \multirow{2}{*}{$\begin{array}{c}X_{4}, \mathrm{scCO}_{2} \text { Flow } \\
(\mathrm{mL} / \mathrm{min})\end{array}$} & \multicolumn{2}{|c|}{ NS Oil Yield (\%) } \\
\hline & & & & & Actual & Predicted \\
\hline 1 & $20(-1)$ & $50(-1)$ & $6(-1)$ & $4(-1)$ & 7.03 & 7.51 \\
\hline 2 & $20(-1)$ & $50(-1)$ & $6(-1)$ & $8(1)$ & 16.47 & 17.07 \\
\hline 3 & $20(-1)$ & $50(-1)$ & $10(1)$ & $4(-1)$ & 9.58 & 10.23 \\
\hline 4 & $20(-1)$ & $50(-1)$ & $10(1)$ & $8(1)$ & 18.63 & 19.79 \\
\hline 5 & $20(-1)$ & $70(1)$ & $6(-1)$ & $4(-1)$ & 6.79 & 6.77 \\
\hline 6 & $20(-1)$ & $70(1)$ & $6(-1)$ & $8(1)$ & 7.62 & 9.53 \\
\hline 7 & $20(-1)$ & $70(1)$ & $10(1)$ & $4(-1)$ & 7.65 & 9.49 \\
\hline 8 & $20(-1)$ & $70(1)$ & $10(1)$ & $8(1)$ & 8.71 & 12.25 \\
\hline 9 & $30(1)$ & $50(-1)$ & $6(-1)$ & $4(-1)$ & 15.95 & 16.70 \\
\hline 10 & $30(1)$ & $50(-1)$ & $6(-1)$ & $8(1)$ & 31.15 & 30.66 \\
\hline 11 & $30(1)$ & $50(-1)$ & $10(1)$ & $4(-1)$ & 20.91 & 19.42 \\
\hline 12 & $30(1)$ & $50(-1)$ & $10(1)$ & $8(1)$ & 30.05 & 33.38 \\
\hline 13 & $30(1)$ & $70(1)$ & $6(-1)$ & $4(-1)$ & 17.13 & 15.96 \\
\hline 14 & $30(1)$ & $70(1)$ & $6(-1)$ & $8(1)$ & 23.59 & 23.12 \\
\hline 15 & $30(1)$ & $70(1)$ & $10(1)$ & $4(-1)$ & 17.65 & 18.68 \\
\hline 16 & $30(1)$ & $70(1)$ & $10(1)$ & $8(1)$ & 24.89 & 25.84 \\
\hline 17 & $15(-\alpha)$ & $60(0)$ & $8(0)$ & $6(0)$ & 10.62 & 5.89 \\
\hline 18 & $35(\alpha)$ & $60(0)$ & $8(0)$ & $6(0)$ & 29.69 & 28.67 \\
\hline 19 & $25(0)$ & $40(-\alpha)$ & $8(0)$ & $6(0)$ & 22.07 & 21.42 \\
\hline 20 & $25(0)$ & $80(\alpha)$ & $8(0)$ & $6(0)$ & 15.05 & 13.14 \\
\hline 21 & $25(0)$ & $60(0)$ & $4(-\alpha)$ & $6(0)$ & 11.22 & 14.56 \\
\hline 22 & $25(0)$ & $60(0)$ & $12(\alpha)$ & $6(0)$ & 21.35 & 19.99 \\
\hline 23 & $25(0)$ & $60(0)$ & $8(0)$ & $2(-\alpha)$ & 6.13 & 8.92 \\
\hline 24 & $25(0)$ & $60(0)$ & $8(0)$ & $10(\alpha)$ & 27.08 & 25.64 \\
\hline 25 & $25(0)$ & $60(0)$ & $8(0)$ & $6(0)$ & 17.71 & 17.28 \\
\hline 26 & $25(0)$ & $60(0)$ & $8(0)$ & $6(0)$ & 18.54 & 17.28 \\
\hline 27 & $25(0)$ & $60(0)$ & $8(0)$ & $6(0)$ & 18.68 & 17.28 \\
\hline 28 & $25(0)$ & $60(0)$ & $8(0)$ & $6(0)$ & 17.55 & 17.28 \\
\hline 29 & $25(0)$ & $60(0)$ & $8(0)$ & $6(0)$ & 21.15 & 17.28 \\
\hline 30 & $25(0)$ & $60(0)$ & $8(0)$ & $6(0)$ & 18.44 & 17.28 \\
\hline
\end{tabular}

Statistical analysis of the CCRD $2^{4}$ model showed that the model is significant. All input variables studied have a statistically significant effect on the NS oil extraction efficiency. The highest impact on oil yield was exerted by pressure followed by $\mathrm{scCO}_{2}$ flow, temperature and time. Analysis of the response surface graphs (Figure 2) and the fitted model equation indicates that the lower the extraction temperature and the higher the pressure, the higher the extraction efficiency from NS seeds. Higher $\mathrm{scCO}_{2}$ flow and longer extraction time also increase the oil yield. 
A
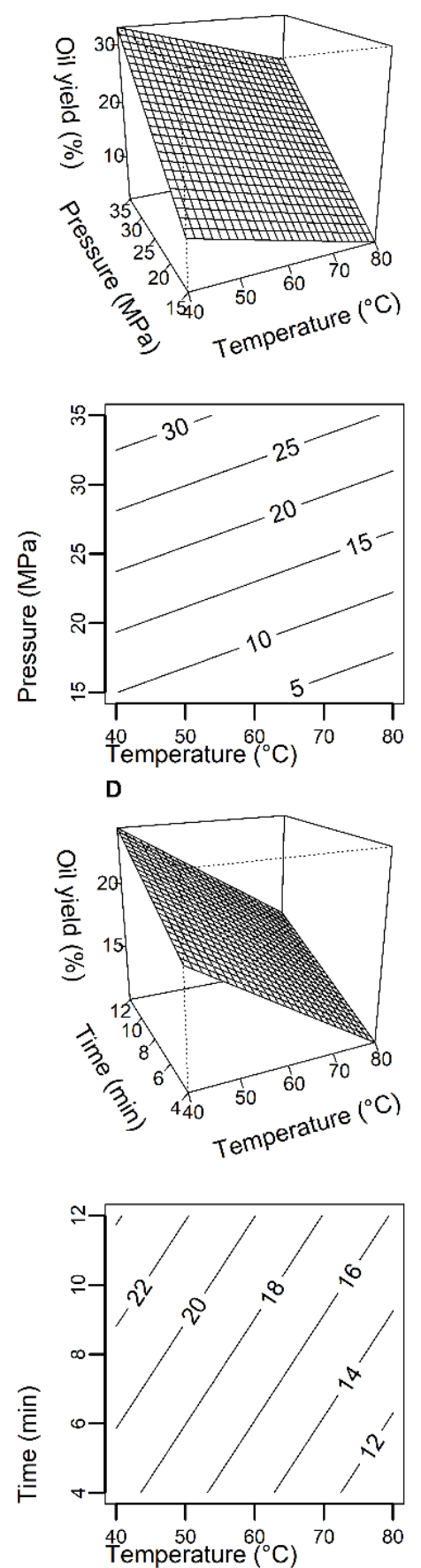

B
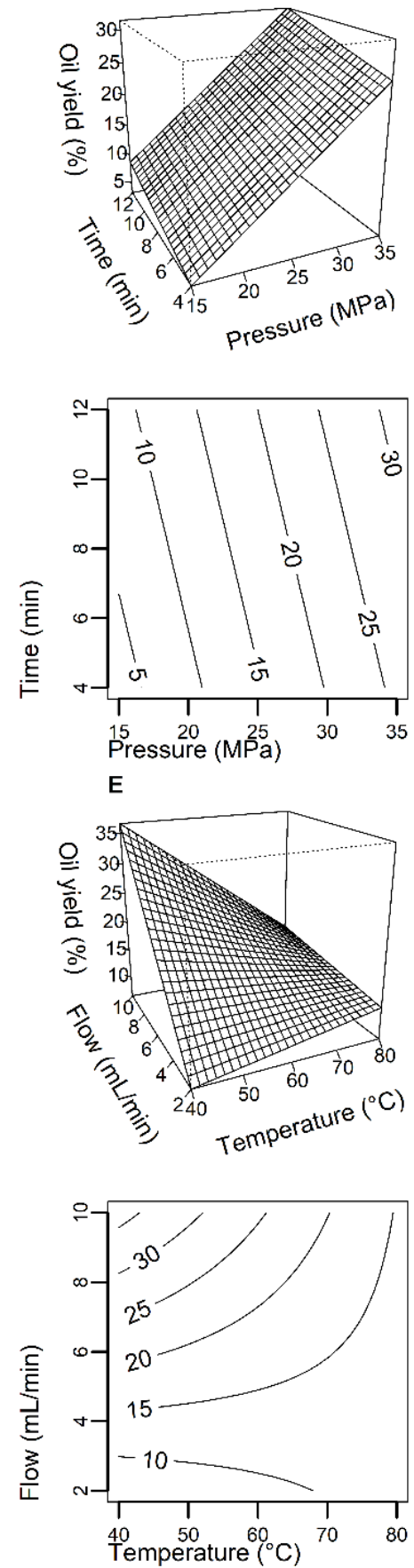

C
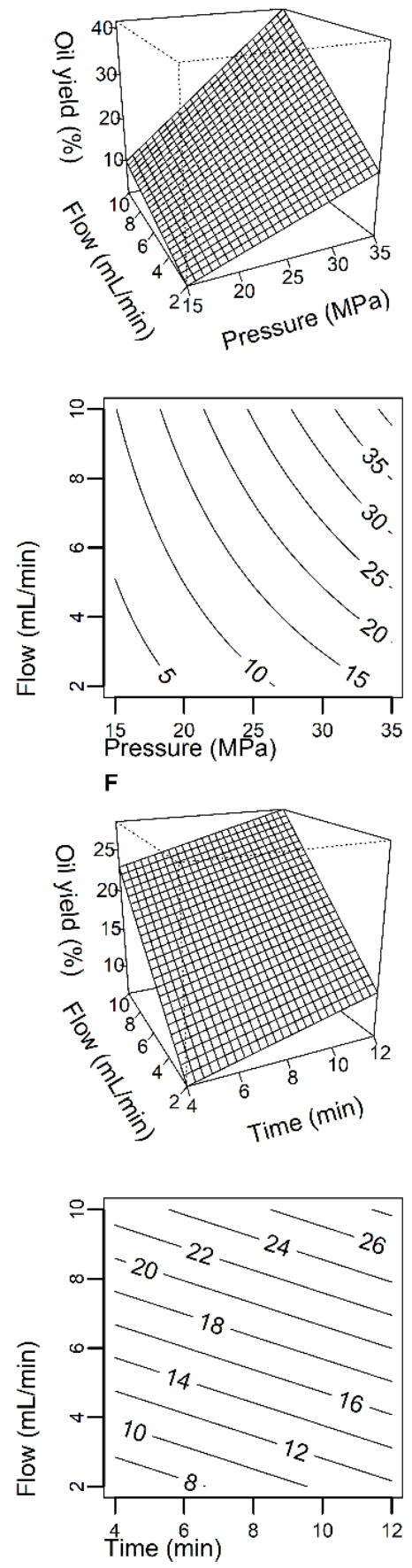

Figure 2. Response surface plots and corresponding contour plots showing the combined effect of pressure and temperature (A), extraction time and pressure $(\mathbf{B}), \mathrm{scCO}_{2}$ flow and pressure (C), extraction time and temperature $(\mathbf{D}), \mathrm{scCO}_{2}$ flow and temperature $(\mathbf{E}), \mathrm{scCO}_{2}$ flow and extraction time on $\mathrm{N}$. sativa oil yield $(\mathbf{F})$. Other variables are fixed at their respective center point (pressure: $25 \mathrm{MPa}$, temperature: $60^{\circ} \mathrm{C}$, time: $8 \mathrm{~min}, \mathrm{scCO}_{2}$ flow: $6 \mathrm{~mL} / \mathrm{min}$ ).

It was found that quadratic relations are insignificant, and the statistically significant interaction occurs between pressure and $\mathrm{scCO}_{2}$ flow as well as temperature and $\mathrm{scCO}_{2}$ flow (Table 2). This might be explained by the impact of both pressure and temperature have on $\mathrm{scCO}_{2}$ density, which can change from $225 \mathrm{~g} / \mathrm{L}$ to $964 \mathrm{~g} / \mathrm{L}$ at different conditions. Factors with negligible impact $(p>0.10)$ were removed from the model. The lack of fit of the model is insignificant. Values of adjusted and predicted coefficient of determination $R^{2}$ are high and in good agreement and are 0.909 and 0.877 , respectively. 
Table 2. Analysis of variance (ANOVA) for central composite rotatable design $2^{4}$.

\begin{tabular}{cccccc}
\hline Source & SS & df & MS & $\boldsymbol{F}$ & $p$ \\
\hline Model & 1415 & 6 & 226 & 49.2 & $<0.0001$ \\
$\mathrm{~A}-\mathrm{scCO}_{2}$ pressure & 782 & 1 & 782 & 163 & $<0.0001$ \\
$\mathrm{~B}-\mathrm{ScCO}_{2}$ temperature & 103 & 1 & 103 & 21.6 & $<0.0001$ \\
$\mathrm{C}-$ Extraction time $_{\mathrm{D}-\mathrm{scCO} \text { flow }}^{4}$ & 44.3 & 1 & 44.3 & 9.25 & 0.0058 \\
$\mathrm{AD}$ & 19.5 & 1 & 419 & 87.6 & $<0.0001$ \\
$\mathrm{BD}$ & 46.4 & 1 & 19.5 & 4.07 & 0.0555 \\
Residual & 110 & 23 & 46.4 & 9.68 & 0.0049 \\
Lack of Fit & 102 & 18 & 5.79 & & \\
Pure Error & 8.40 & 5 & 1.65 & 3.37 & 0.0918 \\
Cor Total & 1525 & 29 & & & \\
\hline
\end{tabular}

The model has a high precision of 26.1 which indicates the adequate signal and can be used to predict the response. Equation of the model:

$$
\text { Yield }(\%)=-30.85+0.479 \cdot P+0.303 \cdot T+0.679 \cdot t+4.44 \cdot F+0.110 \cdot p \cdot F-0.085 \cdot T \cdot F
$$

where $P$ is pressure (MPa), $T$ is temperature $\left({ }^{\circ} \mathrm{C}\right), t$ is time $(\mathrm{min})$ and $F$ is $\mathrm{scCO}_{2}$ flow (mL/min).

\subsection{Kinetics of Extraction}

The extraction curves (Figure 3) were obtained at $40^{\circ} \mathrm{C}$ which was found favorable for essential oils extraction and combinations of pressure and $\mathrm{scCO}_{2}$ flow $(10$ or $15 \mathrm{MPa}$ and 5 or $10 \mathrm{~mL} / \mathrm{min}$, respectively). The asymptotic yield of oil was ca. $28 \%(w / w)$. It was found that mass transfer of NS oil at 10 and $15 \mathrm{MPa}$ is low and the period of constant extraction rate is extended, which allows fractionation of oil from NS (Figure 3).

A significant correlation between TQ content in NS oil and the oil yield was determined and described by logarithmic and power equations (Table 3 ). These observations contribute to better control of the extraction process to obtain the oil with the desired TQ content. The results obtained indicate that in order to isolate oil with high TQ content from the NS seeds, the process should be carried out at a low temperature of $40^{\circ} \mathrm{C}$ and pressure of $10-15 \mathrm{MPa}$. Under these conditions, solubility in $\mathrm{scCO}_{2}$ is higher for essential oils than for the fixed oil. Thus, by controlling the amount of $\mathrm{scCO}_{2}$, i.e., extraction time, a given amount of oil can be obtained with the desired concentration of TQ.

Table 3. Equations describing the relationship between $N$. sativa oil yield $(X)$ and thymoquinone content in oil $(Y)$ in different conditions of pressure and $\mathrm{scCO}_{2}$ flow during extraction at $40{ }^{\circ} \mathrm{C}$.

\begin{tabular}{ccccc}
\hline $\begin{array}{c}\text { Pressure } \\
(\mathbf{M P a})\end{array}$ & $\begin{array}{c}\text { scCO } \\
(\mathbf{m L} \text { Flow }\end{array}$ & Logarithmic Equation & Power Equation & $\boldsymbol{R}^{\mathbf{2}}$ \\
\hline 10 & 5 & $\ln Y=-0.893 \cdot \ln X+2.974$ & $Y=19.0 \cdot X^{-0.893}$ & 0.9979 \\
10 & 10 & $\ln Y=-0.843 \cdot \ln X+2.896$ & $Y=18.1 \cdot X^{-0.843}$ & 0.9987 \\
15 & 5 & $\ln Y=-0.829 \cdot \ln X+2.754$ & $Y=15.7 \cdot X^{-0.829}$ & 0.9997 \\
15 & 10 & $\ln Y=-0.704 \cdot \ln X+2.454$ & $Y=11.6 \cdot X^{-0.704}$ & 0.9972 \\
\hline
\end{tabular}


A

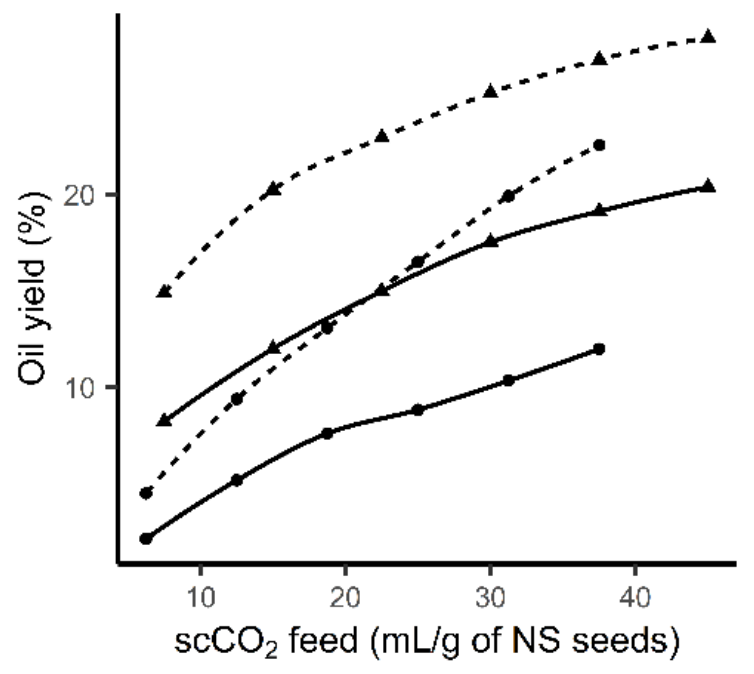

B

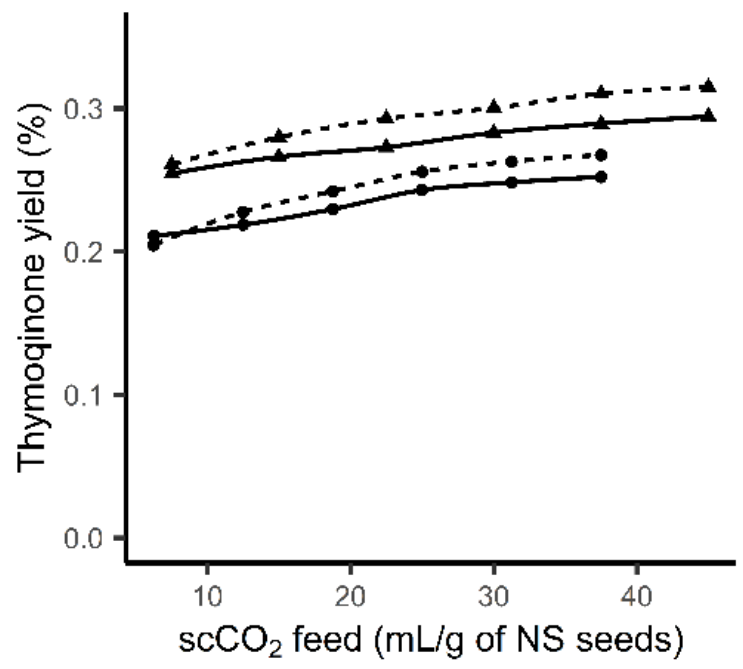

C

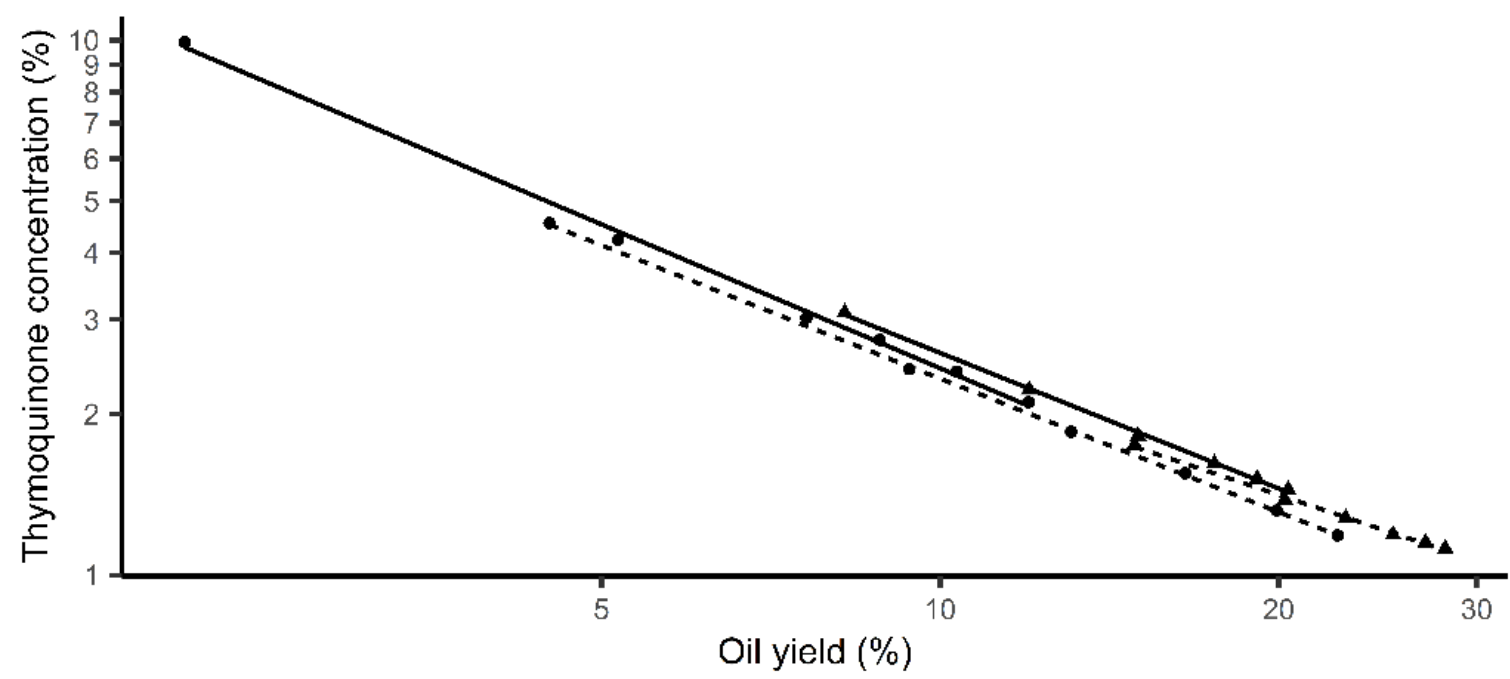

Figure 3. Relationship between NS seed oil yield and $\mathrm{scCO}_{2}$ feed expressed in $\mathrm{mL}$ per $\mathrm{g}$ of $\mathrm{NS}$ seeds obtained by $\mathrm{scCO}_{2}$ extraction at temperature of $40{ }^{\circ} \mathrm{C}$, pressure of $10(-)$ and $15 \mathrm{MPa}(---) \mathrm{scCO}_{2}$ flow of $5(\bullet)$ and $10 \mathrm{~mL} / \mathrm{min}(\mathbf{\Delta})(\mathbf{A})$. Relationship between thymoquinone extraction yield and $\mathrm{scCO}_{2}$ feed expressed in $\mathrm{mL}$ per $\mathrm{g}$ of $\mathrm{NS}$ seeds obtained by scCO extraction at fixed temperature of $40^{\circ} \mathrm{C}$, pressure of $10(-)$ and $15 \mathrm{MPa}(---)$ and $\mathrm{scCO}_{2}$ flow of $5(\bullet)$ and $10 \mathrm{~mL} / \mathrm{min}(\mathbf{\Delta})$ (B). Relationship between N. sativa oil yield and thymoquinone concentration $(\%, w / w)$ in oil during supercritical $\mathrm{CO}_{2}$ extraction at temperature of $40{ }^{\circ} \mathrm{C}$, pressure of $10(-)$ and $15 \mathrm{MPa}(---)$ and $\mathrm{scCO}_{2}$ flow of $5(\bullet)$ and $10 \mathrm{~mL} / \mathrm{min}(\mathbf{\Delta})(\mathbf{C})$. Mean values for three replicates were plotted.

\subsection{Composition of Nigella sativa Seed Oil Fatty Acids}

The results of determination of fatty acid composition of NS oils extracted using conditions employed in the CCRD experiments are presented in Table 4. Different conditions of the extraction haven't significantly altered the contribution of each measured fatty acid to the total of fatty acids content in the NS oil obtained according to the results of ANOVA performed on the data (data analysis not shown). Linoleic acid was the most abundant of the fatty acids constituting $60.3(\mathrm{SD}=1.11) \%$, followed by oleic acid, 22.7 $(\mathrm{SD}=0.76) \%$, palmitic acid, $12.0(\mathrm{SD}=0.65) \%$, stearic acid, $2.4(\mathrm{SD}=0.13) \%$, eicosadienoic acid, $2.4(\mathrm{SD}=0.16) \%$ and myristic acid, $0.2(\mathrm{SD}=0.03) \%$. 
Table 4. Contributions of myristic (C:14), palmitic (C16:0), linoleic (C18:2), oleic (C18:1), stearic (C18:0) and eicosadienoic acids (C20:2) in the total of fatty acids in the NS seed oils obtained at different conditions of $\mathrm{scCO}_{2} \mathrm{pressure}_{\mathrm{scCO}}$ temperature, extraction time and flow of $\mathrm{scCO}_{2}$ (results of FAME analysis by GC-FID).

\begin{tabular}{|c|c|c|c|c|c|c|c|c|c|}
\hline $\begin{array}{l}\text { Pressure } \\
\text { (MPa) }\end{array}$ & $\begin{array}{l}\text { Temperature } \\
\left({ }^{\circ} \mathrm{C}\right)\end{array}$ & $\begin{array}{l}\text { Time } \\
\text { (min) }\end{array}$ & $\begin{array}{c}\mathrm{scCO}_{2} \text { Flow } \\
(\mathrm{mL} / \mathrm{min})\end{array}$ & $\begin{array}{c}\text { C14:0 } \\
(\%)\end{array}$ & $\begin{array}{l}\text { C16:0 } \\
(\%)\end{array}$ & $\begin{array}{c}\text { C18:2 } \\
(\%)\end{array}$ & $\begin{array}{c}\text { C18:1 } \\
(\%)\end{array}$ & $\begin{array}{c}\text { C18:0 } \\
(\%)\end{array}$ & $\begin{array}{c}\text { C20:2 } \\
(\%)\end{array}$ \\
\hline 20 & 50 & 6 & 4 & 0.2 & 11.4 & 60.9 & 22.6 & 2.4 & 2.5 \\
\hline 20 & 50 & 6 & 8 & 0.2 & 12.5 & 60.8 & 21.8 & 2.4 & 2.3 \\
\hline 20 & 50 & 10 & 4 & 0.2 & 12.6 & 61.3 & 21.5 & 2.3 & 2.0 \\
\hline 20 & 50 & 10 & 8 & 0.2 & 12.2 & 60.6 & 22.2 & 2.4 & 2.4 \\
\hline 20 & 70 & 6 & 4 & 0.3 & 13.8 & 57.4 & 23.8 & 2.7 & 2.1 \\
\hline 20 & 70 & 6 & 8 & 0.3 & 13.3 & 58.0 & 24.0 & 2.4 & 2.0 \\
\hline 20 & 70 & 10 & 4 & 0.2 & 12.4 & 57.5 & 25.2 & 2.5 & 2.2 \\
\hline 20 & 70 & 10 & 8 & 0.2 & 13.2 & 60.1 & 21.8 & 2.4 & 2.2 \\
\hline 30 & 50 & 6 & 4 & 0.2 & 11.4 & 61.3 & 22.3 & 2.3 & 2.5 \\
\hline 30 & 50 & 6 & 8 & 0.2 & 11.4 & 61.1 & 22.5 & 2.3 & 2.5 \\
\hline 30 & 50 & 10 & 4 & 0.2 & 11.9 & 60.7 & 22.3 & 2.5 & 2.5 \\
\hline 30 & 50 & 10 & 8 & 0.2 & 11.9 & 60.6 & 22.3 & 2.5 & 2.5 \\
\hline 30 & 70 & 6 & 4 & 0.2 & 11.5 & 60.1 & 23.4 & 2.4 & 2.4 \\
\hline 30 & 70 & 6 & 8 & 0.2 & 11.8 & 59.8 & 23.2 & 2.5 & 2.5 \\
\hline 30 & 70 & 10 & 4 & 0.2 & 11.6 & 59.7 & 23.7 & 2.4 & 2.3 \\
\hline 30 & 70 & 10 & 8 & 0.2 & 11.7 & 60.1 & 23.1 & 2.5 & 2.4 \\
\hline 15 & 60 & 8 & 6 & 0.2 & 11.7 & 61.2 & 22.5 & 2.2 & 2.2 \\
\hline 35 & 60 & 8 & 6 & 0.2 & 11.9 & 60.6 & 22.3 & 2.4 & 2.5 \\
\hline 25 & 40 & 8 & 6 & 0.2 & 10.6 & 62.3 & 22.3 & 2.1 & 2.5 \\
\hline 25 & 80 & 8 & 6 & 0.2 & 12.0 & 60.8 & 22.3 & 2.3 & 2.3 \\
\hline 25 & 60 & 4 & 6 & 0.3 & 11.4 & 60.6 & 22.8 & 2.5 & 2.5 \\
\hline 25 & 60 & 12 & 6 & 0.2 & 12.0 & 60.9 & 22.2 & 2.3 & 2.4 \\
\hline 25 & 60 & 8 & 2 & 0.2 & 11.4 & 61.1 & 22.5 & 2.3 & 2.4 \\
\hline 25 & 60 & 8 & 10 & 0.2 & 12.5 & 58.7 & 23.3 & 2.7 & 2.6 \\
\hline 25 & 60 & 8 & 6 & 0.2 & 11.9 & 60.7 & 22.4 & 2.4 & 2.5 \\
\hline
\end{tabular}

\subsection{Antibacterial Activity of Nigella sativa Seed Extracts}

Results of determination of selected human bacterial pathogens susceptibility to NSE1, NSE2, TQ, AMC/DCBA and CHQ are collected in Table 5. The strains determined as the most susceptible to TQ and NS seed oils were Haemophilus influenzae ATCC 43065, Staphylococcus haemolyticus ATCC 29970, Staphylococcus epidermidis ATCC 14990 and Enterococcus faecalis ATCC 19433 and with TQ MIC and MBC ranging from 4 to $16 \mu \mathrm{g} / \mathrm{mL}$ and 8 to $32 \mu \mathrm{g} / \mathrm{mL}$, respectively. The antibacterial effectiveness of NS seed oils used in the experiments against the susceptible strains corresponded with their thymoquinone content. The remaining strains examined were less susceptible to TQ and NS seed oil with MIC of TQ $\geq 128 \mu \mathrm{g} / \mathrm{mL}$, MIC of NSE1 $\geq 1.28 \mathrm{mg} / \mathrm{mL}$ and MIC of NSE2 $\geq 6.40 \mathrm{mg} / \mathrm{mL}$. For most of the susceptible strains the MBC value of TQ and the NS seed oils were observed at respective MIC or $2 \times$ MIC. 
Table 5. Minimal inhibitory concentrations (MIC) or minimal bactericidal concentrations (MBC) of thymoquinone (TQ), thymol (THY), p-cymene (CY), Nigella sativa seed extracts obtained by supercritical $\mathrm{CO}_{2}$, extraction (NSE1 and NSE2), chlorquinaldol (CHQ) and a combination of amylmetacresol and 2,4-dichlorobenzyl alcohol (AMC/DCBA) in a 1:2 molar ratio against chosen pathogenic bacteria. For AMC/DCBA combination the concentration of amylmetacresol was presented.

\begin{tabular}{|c|c|c|c|c|c|c|c|c|c|c|}
\hline \multirow[t]{2}{*}{ Strain } & \multicolumn{2}{|c|}{$\begin{array}{c}\text { NSE1 } \\
(\mathrm{mg} / \mathrm{mL})\end{array}$} & \multicolumn{2}{|c|}{$\begin{array}{c}\text { NSE2 } \\
(\mathrm{mg} / \mathrm{mL})\end{array}$} & \multicolumn{2}{|c|}{$\begin{array}{c}\text { TQ } \\
(\mu \mathrm{g} / \mathrm{mL})\end{array}$} & \multicolumn{2}{|c|}{$\begin{array}{c}\text { AMC/DCBA } \\
(\mu \mathrm{g} / \mathrm{mL})\end{array}$} & \multicolumn{2}{|c|}{$\begin{array}{c}\text { CHQ } \\
(\mu \mathrm{g} / \mathrm{mL})\end{array}$} \\
\hline & MIC & MBC & MIC & MBC & MIC & MBC & MIC & MBC & MIC & MBC \\
\hline H. influenzae ATCC 43065 & 0.04 & 0.08 & 0.20 & 0.40 & 4 & 8 & 128 & 128 & 4 & 16 \\
\hline S. haemolyticus ATCC 29970 & 0.08 & 0.08 & 0.40 & 0.40 & 8 & 8 & 128 & 128 & 4 & 32 \\
\hline S. epidermidis ATCC 14990 & 0.08 & 0.32 & 0.4 & 1.6 & 8 & 32 & 32 & 32 & 16 & 64 \\
\hline E. faecalis ATCC 19433 & 0.16 & 0.32 & 0.80 & 1.60 & 16 & 32 & 64 & 128 & 8 & 16 \\
\hline E. coli ATCC 25922 & 1.28 & 1.28 & 6.40 & 6.40 & 128 & 128 & 256 & 512 & 16 & 64 \\
\hline S. sonnei ATCC 9290 & 2.56 & $>5.12$ & 12.80 & $>25.6$ & 256 & $>512$ & 128 & 256 & 16 & 64 \\
\hline S. odorifera ATCC 33077 & 5.12 & $>5.12$ & 25.60 & $>25.6$ & 512 & $>512$ & 128 & 512 & 64 & 64 \\
\hline S. typhimurium ATCC 13311 & 5.12 & $>5.12$ & 25.60 & $>25.6$ & 512 & $>512$ & 64 & 128 & 32 & 64 \\
\hline
\end{tabular}

\section{Discussion}

Supercritical carbon dioxide extraction has been applied by researchers to collect biologically active extracts from NS seeds as this technique is considered reliable, efficient, provides space for adjustments to the extraction conditions and produces solvent-free products. The reports available in the literature concerning $\mathrm{scCO}_{2}$ extracts from $\mathrm{NS}$ seeds focus on chemical or biological properties of obtained extracts and present specific conditions at which the extracts were collected. The extracts properties and composition as well as the extraction yield varied among the studies due to different plant material and extraction conditions $[19,28,29]$. The studies presented in this work provide practical and comprehensive understanding of the influence of $\mathrm{scCO}_{2}$ extraction conditions on the extraction yield and demonstrate applicability of RSM and CCDR in as the framework for optimization of parameters for extraction of oils from NS seeds. Such an approach is a costand time-effective alternative to full factorial designs, which require a greater number of trials and has been applied by Salea et al. [26] in their work demonstrating applicability of Taguchi design as a mean for economical optimization of the $\mathrm{scCO}_{2}$ extraction from NS seeds. The presented kinetics of the oil and TQ extraction at low temperature and pressure exhibit a possibility of convenient and efficient separation of the TQ-rich fractions of the NS seed oil, while not compromising the efficiency of the overall TQ extraction. Kinetics studies of $\mathrm{scCO}_{2}$ extraction from NS seeds haven't been reported in the available literature, however the results presented in this work are in agreement with kinetics of TQ and waxes extraction from aerial parts Monarda didyma and M. fistulosa studied by Sovova et al. [30]. The composition of fatty acids present in the oils extracted in this study hasn't been shown to be significantly affected by the extraction conditions and was found to be typical for NS seed oil $[1,27,28]$.

Supercritical fluids are characterized by viscosity similar to gases, density to liquids and high diffusivity. They have a variable solubility force that depends on their pressure and temperature. The lower the pressure and the higher the temperature, the $\mathrm{scCO}_{2}$ has lower density, and also a higher diffusion coefficient and permeability. On the other hand, too high diffusion coefficient preclude fractionation because compounds with different solubilities (i.e., essential oil and fatty acids glycerol esters) mix easily. In addition, the high temperature also lowers the viscosity of the fixed oil in seeds. The results obtained in this work indicate that the key to isolating the fraction with the highest concentration of thymoquinone with $\mathrm{scCO}_{2}$ is the use of the low temperature to maintain a moderate $\mathrm{scCO}_{2}$ density $\left(578 \mathrm{~g} / \mathrm{mL}\right.$ and $750 \mathrm{~g} / \mathrm{mL}$ at $40{ }^{\circ} \mathrm{C}$ and the pressure of $10 \mathrm{MPa}$ and $15 \mathrm{MPa}$, respectively) and low flow of $\mathrm{scCO}_{2}$ which allows to capture the right mass or volume of extract in a separator when collecting the thymoquinone-rich fraction. 
The antibacterial activity of NS seed oil and TQ shown in this work remain in agreement with results of previous research on the topic. The NS seed extracts obtained with use of various techniques as well as TQ have been demonstrated to have a strong bactericidal effect against $S$. aureus and S. epidermidis $[17,28,31-33]$. The antibacterial effects of NS seed oil and TQ against $H$. influenzae and S. haemolyticus shown in this work hasn't been previously demonstrated and suggest applicability of the oil and TQ against a broad spectrum of bacterial pathogens. The results concerning NS seed extracts and TQ efficiency against E. coli, E. faecalis shown in this study and present in the available literature might indicate on strain-dependency of susceptibility these bacteria to the tested substances $[16,19,28,32]$. The antibacterial effects of NS seed oil were observed to be strongly dependent on the final TQ concentration in the samples.

\section{Materials and Methods}

\subsection{Optimization of Supercritical Carbon Dioxide Extraction from Nigella sativa Seeds 4.1.1. Plant Material and Extraction Equipment}

Nigella sativa L. seeds were purchased from FZL company from Poland, batch number F4568. The Voucher specimen No WLDK/2013 is stored at Biovico, Gdynia, Poland. The seeds were ground with a Bosch KM13 grinder (Bosch, Munich, Germany), $10 \mathrm{~g}$ at once for $2 \mathrm{~min}$. Ground seeds ( $4.0 \mathrm{~g}$ ) were put in $10 \mathrm{~mL}$ stainless steel extraction vessels. Supercritical $\mathrm{CO}_{2}$ extraction of NS seed oil was performed with a Waters MV-10 ASFE (Waters Corporation, Milford, MA, USA) extractor at different conditions of temperature, pressure, extraction time, and $\mathrm{scCO}_{2}$ flow (Figure 4). $\mathrm{CO}_{2}$ of $99.995 \%$ purity (AirLiquide, Cracow, Poland) was used for extraction of NS oil.

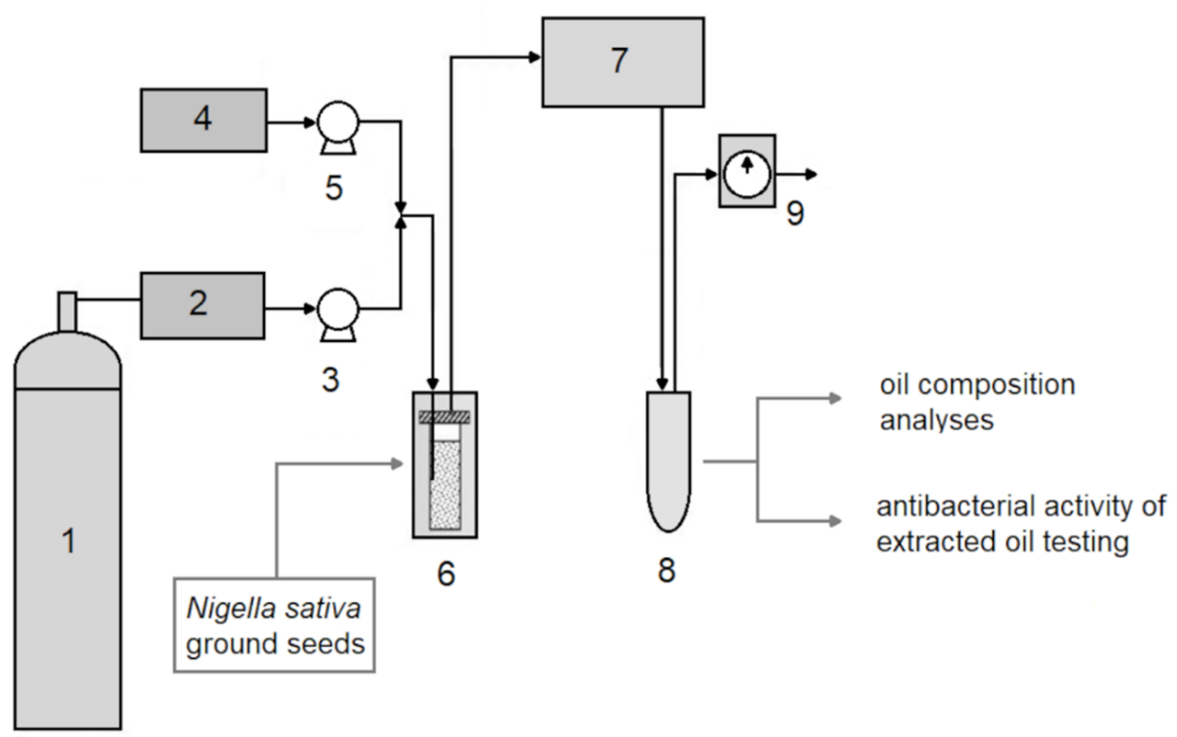

Figure 4. Flow diagram of a supercritical carbon dioxide extraction system $\left(1 . \mathrm{CO}_{2}\right.$ supply; 2 . cooling heat exchanger; $3 . \mathrm{CO}_{2}$ pump; 4. co-solvent vessel; 5. co-solvent pump; 6. extraction oven with extraction vessels; 7. backpressure regulator; 8 . sample collection; 9. wet gas meter and $\mathrm{CO}_{2}$ release).

\subsubsection{Modelling of Oil Extraction from the Nigella sativa Seeds}

The analysis of the effects of pressure, temperature, extraction time and $\mathrm{scCO}_{2}$ flow on the oil extraction efficiency from NS seeds was performed using a central composite rotatable design (CCRD) with response surface methodology (RSM). The experimental design used in this study was a $2^{4}$ factorial CCRD. Levels of independent variables are shown in Table 6 while the experimental matrix is shown in Table 1. 
Table 6. Levels of variables in central composite rotatable design $2^{4}$ experiment.

\begin{tabular}{cccccc}
\hline Independent Variables & \multicolumn{5}{c}{ Levels } \\
\cline { 2 - 5 } & $-\boldsymbol{\alpha}$ & $\mathbf{- 1}$ & $\mathbf{0}$ & $\mathbf{1}$ & $\boldsymbol{\alpha}$ \\
\hline$X_{1}-\mathrm{scCO}_{2}$ pressure $(\mathrm{MPa})$ & 15 & 20 & 25 & 30 & 35 \\
$\mathrm{X}_{2}-\mathrm{scCO}_{2}$ temperature $\left({ }^{\circ} \mathrm{C}\right)$ & 40 & 50 & 60 & 70 & 80 \\
$\mathrm{X}_{3}-\mathrm{Extraction}$ time $(\mathrm{min})$ & 4 & 6 & 8 & 10 & 12 \\
$X_{4}-\mathrm{scCO}_{2}$ flow $(\mathrm{mL} / \mathrm{min})$ & 2 & 4 & 6 & 8 & 10 \\
\hline
\end{tabular}

The relationship of the extraction parameters (independent variables) and NS oil yield (the response) was fitted to a predictive second order polynomial equation:

$$
\left.Y_{i}=\beta_{0}+\sum_{i=1}^{n} \beta_{i} X_{i}+\sum_{i=1}^{n} \beta_{i i} X_{i}^{2}+\sum_{i=1}^{n-1} \sum_{j=i+1}^{n} \beta_{i j} X_{i} X_{j}\right)
$$

where $Y_{i}$ is the predicted response (NS oil yield), subscripts $i$ and $j$ have values from 1 to the number of variables; $\beta_{0}$ is a constant; $\beta_{i}$, linear coefficient; $\beta_{i i}$, the quadratic coefficient; $\beta_{i j}$, cross-product coefficient; $n$, number of factors and $X_{i}$ and $X_{j}$ are the coded dimensionless values of the analyzed variables. The software Design-Expert 7 (Stat-Ease, Minneapolis, MN, USA) was used for experimental design, the analysis of variance (ANOVA), and graphical analysis of the data. The statistical significance of the model was expressed by an $F$-test and the quality of its fit was evaluated by the coefficient of determination $R^{2}$. The significance of the regression coefficients was tested by the Student's $t$-test and the $p$ values were used to determine the significance of each coefficient.

\subsubsection{Kinetics of Thymoquinone and Oil Extraction}

In order to investigate the kinetics of extraction of TQ and oil from NS seeds, extraction was carried out in different operating pressure of 10 and $15 \mathrm{MPa}, \mathrm{scCO}_{2}$ flow of 5 and $10 \mathrm{~mL} / \mathrm{min}$ and extraction time from 3 to $24 \mathrm{~min}$. Those conditions were chosen basing on the results of modelling of oil extraction from the NS seeds. All extractions were triplicated. The extracts were accurately weighted and submitted to GC-MS analysis in order to establish thymoquinone content.

\subsection{Oil Composition Analyses}

\subsubsection{Gas Chromatography-Mass Spectrometry Analysis (GC-MS)}

Chemical composition of oils obtained by scCO $\mathrm{CO}_{2}$ extraction was analyzed using PerkinElmer ${ }^{\circledR}$ Clarus $^{\circledR} 500$ (PerkinElmer, Waltham, MA, USA) gas chromatograph equipped with PerkinElmer ${ }^{\circledR}$ Clarus $^{\circledR} 500$ mass spectrometer and controlled by PerkinElmer ${ }^{\circledR}$ TurboMass ${ }^{\mathrm{TM}}$ GC $/$ MS software v. 5.0 using NIST spectral libraries v. 2.0.0. PerkinElmer ${ }^{\circledR}$ Elite-5MS $(30 \mathrm{~m} \times 0.25 \mathrm{~mm}$, $0.25 \mu \mathrm{m}$ ) was the column used for these analyses. Prior to the analyses the $20 \mu \mathrm{L}$ of each oil sample was diluted in $380 \mu \mathrm{L}$ of isooctane. The injection volume was $1 \mu \mathrm{L}$ in split mode 1:10, injector temperature was $250^{\circ} \mathrm{C}$, flow rate was $1.5 \mathrm{~mL} / \mathrm{min}$ and the electron ionization energy was $70 \mathrm{eV}$. Initial oven temperature of $40^{\circ} \mathrm{C}$ was increased to $200{ }^{\circ} \mathrm{C}$ after $5 \mathrm{~min}$ at a rate of $10^{\circ} \mathrm{C} / \mathrm{min}$, then increased to $280^{\circ} \mathrm{C}$ at a rate of $5^{\circ} \mathrm{C} / \mathrm{min}$ and held for $8 \mathrm{~min}$. Standards and solvent were obtained from Sigma-Aldrich, Poznan, Poland. Each analysis was made in triplicate.

\subsubsection{Gas Chromatography Fatty Acid Analysis}

Composition of fatty acids in extracted NS seed oils was analyzed using PerkinElmer ${ }^{\circledR}$ Clarus ${ }^{\circledR}$ 500 gas chromatograph with flame-ionization detector controlled by PerkinElmer ${ }^{\circledR}$ TotalChrom $^{\mathrm{TM}}$ software v. 6.3 .2 and the column used was PerkinElmer ${ }^{\circledR}$ Elite-5MS $(30 \mathrm{~m} \times 0.25 \mathrm{~mm}, 0.25 \mu \mathrm{m})$. Prior to the analysis $20 \mu \mathrm{L}$ of oil was dissolved in $0.4 \mathrm{~mL}$ of $0.5 \mathrm{M} \mathrm{KOH}$ in methanol and incubated for $5 \mathrm{~min}$ in $100{ }^{\circ} \mathrm{C}$ to hydrolyze the triacylglycerols, then $0.35 \mathrm{~mL}$ of $20 \% \mathrm{BF}_{3}$ in methanol was added and samples were incubated for $5 \mathrm{~min}$ in $100^{\circ} \mathrm{C}$ to produce fatty acid methyl esters (FAME). After cooling to room temperature $0.5 \mathrm{~mL}$ of saturated $\mathrm{NaCl}$ water 
solution and $0.5 \mathrm{~mL}$ of isooctane were added and samples were vortex-mixed. Isooctane fraction was collected for GC analysis. Standard solutions of methyl myristate, methyl palmitate, methyl linoleate, methyl oleate, methyl stearate and methyl eicosadienoate were prepared in isooctane. Injection volume was $0.5 \mu \mathrm{L}$ in split mode 1:10, injector temperature was $250{ }^{\circ} \mathrm{C}$, flow rate was $1.5 \mathrm{~mL} / \mathrm{min}$ and FID temperature was $250{ }^{\circ} \mathrm{C}$. Initial oven temperature of $180{ }^{\circ} \mathrm{C}$ was increased to $195{ }^{\circ} \mathrm{C}$ after $2 \mathrm{~min}$ at a rate of $1^{\circ} \mathrm{C} / \mathrm{min}$, then increased to $250{ }^{\circ} \mathrm{C}$ at a rate of $7{ }^{\circ} \mathrm{C} / \mathrm{min}$ and held for $5 \mathrm{~min}$. The FAME standards applied were obtained from Sigma-Aldrich. Analyzes were made in triplicates.

\subsection{Antibacterial Activity of Nigella sativa Seed Oil \\ 4.3.1. Bacterial Strains}

Eight human bacterial pathogens were represented by reference strains: Staphylococcus haemolyticus ATCC 29970, Staphylococcus epidermidis ATCC 14990, Enterococcus faecalis ATCC 19433, Escherichia coli ATCC 25922, Haemophilus influenzae ATCC 43065, Salmonella typhimurium ATCC 13311, Serratia odorifera ATCC 33077 and Shigella sonnei ATCC 9290.

\subsubsection{Preparation of Nigella sativa Seed Oils for Evaluation of Antibacterial Activity}

Freshly ground NS seeds were extracted with $\mathrm{scCO}_{2}$ at $40{ }^{\circ} \mathrm{C}$ and pressure of $10 \mathrm{MPa}$, flow $5 \mathrm{~mL} / \mathrm{min}$ for $10 \mathrm{~min}$ to obtain NSE1 oil with high concentration of TQ (9.91\%). The oil fraction NSE2 containing lower TQ concentration (2.10\%) was obtained by prolongation of the extraction at these conditions to total of $30 \mathrm{~min}$.

\subsubsection{Minimum Inhibitory Concentration Determinations}

Minimum inhibitory concentrations (MIC) were determined with use of a broth microdilution protocol following Clinical and Laboratory Standards Institute guidelines [30]. Stock solutions of TQ, chlorquinaldol (CHQ) and NS oils were prepared in dimethyl sulfoxide (DMSO), while the stock solution of a composition of amylmetacresol with 2,4-dichlorobenzyl alcohol in 1:2 molar ratio (AMC/DCBA) was prepared in ethanol. Maximum final concentrations were $512 \mu \mathrm{g} / \mathrm{mL}$ for TQ and CHQ, $512 \mu \mathrm{g} / \mathrm{mL}$ of AMC with $1024 \mu \mathrm{g} / \mathrm{mL}$ of DCBA in AMC/DCBA samples. Two variants of $N$. sativa oil, NSE1 and NSE2 $(9.91 \%$ and $2.10 \%$ of TQ, respectively) were used at maximum final concentrations of $5.12 \mathrm{mg} / \mathrm{mL}$ and $25.6 \mathrm{mg} / \mathrm{mL}$. Two-fold serial dilutions in Mueller-Hinton broth (MHB) were prepared on 96-well plates. DMSO and ethanol were used as controls. Overnight bacterial cultures were diluted in fresh MHB medium and cultured to obtain log phase, then bacterial suspensions of $10^{6} \mathrm{CFU} / \mathrm{mL}$ in $\mathrm{MHB}$ were prepared and used to inoculate the 96-well plates. Plates were then incubated for $24 \mathrm{~h}$ in $37^{\circ} \mathrm{C}$ in sealed plates to prevent TQ evaporation. Standards of antibacterial agents, MHB and solvents were obtained from Sigma-Aldrich.

\subsubsection{Minimum Bactericidal Concentration Determinations}

Minimum bactericidal concentrations (MBC) were determined by sub-culturing samples collected from the wells of microtiter plates after the broth microdilution assay performed to determine MIC values for tested substances. Samples from the wells showing no visible growth were serially diluted in sterile $0.85 \% \mathrm{NaCl}$ and $10 \mu \mathrm{L}$ of each sample was spread on Mueller-Hinton agar plates. After $24 \mathrm{~h}$ incubation at $37^{\circ} \mathrm{C}$, the colonies were counted and results were compared to control. Minimum concentration reducing viable cell count by $\geq 99.9 \%$ was considered as MBC.

\subsection{Statistical Analyses}

All experiments were performed in three or more repetitions. Statistical analyses of the extraction models were performed using Design-Expert 7 (Stat-Ease, Minneapolis, MN, USA). Differences between means were analyzed with the Student's $t$-test for independent samples with Microsoft Excel Data Analysis Tool Pack and considered significant if $p$ value was below 0.05 . 


\section{Conclusions}

In the course of presented work influence of $\mathrm{scCO}_{2}$ extraction conditions, i.e., $\mathrm{scCO}_{2}$ flow rate, temperature, pressure and extraction time on extraction yield of $N$. sativa seed oil, as well as extraction kinetics regarding total oil and thymoquinone were defined. The dependencies were expressed with a reliable mathematical model, which facilitates planning of extraction towards obtaining oil of desired final composition, especially thymoquinonerich fractions for use in cosmetic and curative formulations and fixed oil fraction appropriate for use in food industry as the fatty acid composition was not significantly affected by extraction conditions. The optimized $\mathrm{scCO}_{2}$ extraction was used to collect thymoquinonerich $N$. sativa seed oils. Examination of antibacterial activity of the oils substantiate the importance of separation of thymoquinone-rich $N$. sativa oil fractions as their bactericidal activity against pathogenic bacteria, which might contribute to establishment of novel efficient means of preventing bacterial infections, was demonstrated.

Author Contributions: Conceptualization, G.G., W.K., L.K. and B.B.; investigation, G.G., W.K., R.Ł., L.K. and B.B.; methodology, G.G., W.K., L.K. and B.B.; project administration, L.K.; resources, G.G., W.K. and R.Ł.; supervision, L.K. and B.B.; visualization, G.G.; writing-original draft, G.G.; W.K. and L.K.; writing-review and editing, R.Ł., L.K. and B.B. All authors have read and agreed to the published version of the manuscript.

Funding: This research was supported by the EU and The National Centre for Research and Development grant: imNutra POIG.01.04.00-22-183/12 under "Innovative Economy" Operational Programme, 2007-2013, Priority 1.4 .

Institutional Review Board Statement: Not applicable.

Informed Consent Statement: Not applicable.

Data Availability Statement: Not applicable.

Conflicts of Interest: The authors declare that there is no conflict of interest regarding the publication of this article.

Sample Availability: Not available.

\section{References}

1. Cheikh-Rouhou, S.; Besbes, S.; Hentati, B.; Blecker, C.; Deroanne, C.; Attia, H. Nigella sativa L.: Chemical composition and physicochemical characteristics of lipid fraction. Food Chem. 2007, 101, 673-681. [CrossRef]

2. Ramadan, M.F. Nutritional value, functional properties and nutraceutical applications of black cumin (Nigella sativa L.): An overview. Int. J. Food Sci. Technol. 2007, 42, 1208-1218. [CrossRef]

3. Ramadan, M.F.; Mörsel, J.T. Analysis of glycolipids from black cumin (Nigella sativa L.), coriander (Coriandrum sativum L.) and niger (Guizotia abyssinica Cass.) oilseeds. Food Chem. 2003, 80, 197-204. [CrossRef]

4. Darakhshan, S.; Bidmeshki Pour, A.; Hosseinzadeh Colagar, A.; Sisakhtnezhad, S. Thymoquinone and its therapeutic potentials. Pharmacol. Res. 2015, 95-96, 138-158. [CrossRef]

5. Ali, B.H.; Blunden, G. Pharmacological and toxicological properties of Nigella sativa. Phyther. Res. 2003, 17, 299-305. [CrossRef]

6. Khan, M.A. Chemical composition and medicinal properties of Nigella sativa Linn. Inflammopharmacology 1999, 7, 15-35. [CrossRef] [PubMed]

7. Salem, M.L. Immunomodulatory and therapeutic properties of the Nigella sativa L. seed. Int. Immunopharmacol. 2005, 5, 1749-1770. [CrossRef] [PubMed]

8. Amin, B.; Hosseinzadeh, H. Black Cumin (Nigella sativa) and Its Active Constituent, Thymoquinone: An Overview on the Analgesic and Anti-inflammatory Effects. Planta Med. 2016, 82, 8-16. [CrossRef]

9. Khan, S.A.; Khan, A.M.; Karim, S.; Kamal, M.A.; Damanhouri, G.A.; Mirza, Z. Panacea seed "Nigella": A review focusing on regenerative effects for gastric ailments. Saudi J. Biol. Sci. 2016, 23, 542-553. [CrossRef]

10. Khalife, K.H.; Lupidi, G. Reduction of hypervalent states of myoglobin and hemoglobin to their ferrous forms by thymoquinone: The role of GSH, NADH and NADPH. Biochim. Biophys. Acta. 2008, 1780, 627-637. [CrossRef] [PubMed]

11. Mansour, M.A.; Nagi, M.N.; El-Khatib, A.S.; Al-Bekairi, A.M.; Al-Bekairi, M.A. Effects of Thymoquinone on Antioxidant Enzyme Activities, Lipid Peroxidation and Dt-Diaphorase in Different Tissues of Mice; A Possible Mechanism of Action. Cell Biochem. Funct. 2002, 20, 143-151. [CrossRef] [PubMed]

12. Abukhader, M. Thymoquinone in the clinical treatment of cancer: Fact or fiction? Pharmacogn. Rev. 2013, 7, 117-120. [CrossRef] [PubMed] 
13. Woo, C.C.; Kumar, A.P.; Sethi, G.; Tan, K.H.B. Thymoquinone: Potential cure for inflammatory disorders and cancer. Biochem. Pharmacol. 2012, 83, 443-451. [CrossRef] [PubMed]

14. Ghayur, M.N.; Gilani, A.H.; Janssen, L.J. Intestinal, airway, and cardiovascular relaxant activities of thymoquinone. Evid.-Based Complement. Altern. Med. 2012, 2012, 305319. [CrossRef] [PubMed]

15. Khan, M.A.U.; Ashfaq, M.K.; Zuberi, H.S.; Mahmood, M.S.; Gilani, A.H. The in vivo antifungal activity of the aqueous extract from Nigella sativa seeds. Phytother. Res. 2003, 17, 183-186. [CrossRef]

16. Chaieb, K.; Kouidhi, B.; Jrah, H.; Mahdouani, K.; Bakhrouf, A. Antibacterial activity of Thymoquinone, an active principle of Nigella sativa and its potency to prevent bacterial biofilm formation. BMC Complement. Altern. Med. 2011, 11, 29. [CrossRef]

17. Gawron, G.; Krzyczkowski, W.; Lemke, K.; Ołdak, A.; Kadziński, L.; Banecki, B. Nigella sativa seed extract applicability in preparations against methicillin-resistant Staphylococcus aureus and effects on human dermal fibroblasts viability. J. Ethnopharmacol. 2019, 244, 112135. [CrossRef]

18. Jrah Harzallah, H.; Kouidhi, B.; Flamini, G.; Bakhrouf, A.; Mahjoub, T. Chemical composition, antimicrobial potential against cariogenic bacteria and cytotoxic activity of Tunisian Nigella sativa essential oil and thymoquinone. Food Chem. 2011, 129, 1469-1474. [CrossRef]

19. Kokoska, L.; Havlik, J.; Valterova, I.; Sovova, H.; Sajfrtova, M.; Jankovska, I. Comparison of Chemical Composition and Antibacterial Activity of Nigella sativa Seed Essential Oils Obtained by Different Extraction Methods. J. Food Prot. 2008, 71, 2475-2480. [CrossRef]

20. Azmir, J.; Zaidul, I.S.M.; Rahman, M.M.; Sharif, K.M.; Mohamed, A.; Sahena, F.; Jahurul, M.H.A.; Ghafoor, K.; Norulaini, N.A.N.; Omar, A.K.M. Techniques for extraction of bioactive compounds from plant materials: A review. J. Food Eng. 2013, 117, 426-436. [CrossRef]

21. Nguyen, V.T.; Bowyer, M.C.; Van Vuong, Q.; Altena, I.A.; Van Scarlett, C.J. Phytochemicals and antioxidant capacity of Xao tam phan (Paramignya trimera) root as affected by various solvents and extraction methods. Ind. Crops Prod. 2015, 67, 192-200. [CrossRef]

22. Brunner, G. Supercritical fluids: Technology and application to food processing. J. Food Eng. 2005, 67, 21-33. [CrossRef]

23. Sharif, K.M.; Rahman, M.M.; Azmir, J.; Mohamed, A.; Jahurul, M.H.A.; Sahena, F.; Zaidul, I.S.M. Experimental design of supercritical fluid extraction-A review. J. Food Eng. 2014, 124, 105-116. [CrossRef]

24. Baldino, L.; Scognamiglio, M.; Reverchon, E. Extraction of rotenoids from Derris elliptica using supercritical $\mathrm{CO}_{2}$. J. Chem. Technol. Biotechnol. 2018, 93, 3656-3660. [CrossRef]

25. Mohammed, N.K.; Abd Manap, M.Y.; Tan, C.P.; Muhialdin, B.J.; Alhelli, A.M.; Hussin, A.S.M. The Effects of Different Extraction Methods on Antioxidant Properties, Chemical Composition, and Thermal Behavior of Black Seed (Nigella sativa L.) Oil. Evid.-Based Complement. Altern. Med. 2016, 2016, 6273817. [CrossRef]

26. Salea, R.; Widjojokusumo, E.; Hartanti, A.W.; Veriansyah, B.; Tjandrawinata, R.R. Supercritical fluid carbon dioxide extraction of Nigella sativa (black cumin) seeds using taguchi method and full factorial design. Biochem. Compd. 2013, 1. [CrossRef]

27. Solati, Z.; Baharin, B.S.; Bagheri, H. Supercritical carbon dioxide $\left(\mathrm{SC}-\mathrm{CO}_{2}\right)$ extraction of Nigella sativa L. oil using full factorial design. Ind. Crops Prod. 2012, 36, 519-523. [CrossRef]

28. Piras, A.; Rosa, A.; Marongiu, B.; Porcedda, S.; Falconieri, D.; Dessì, M.A.; Ozcelik, B.; Koca, U. Chemical composition and in vitro bioactivity of the volatile and fixed oils of Nigella sativa L. extracted by supercritical carbon dioxide. Ind. Crops Prod. 2013, 46, 317-323. [CrossRef]

29. Venkatachallam, S.K.T.; Pattekhan, H.; Divakar, S.; Kadimi, U.S. Chemical composition of Nigella sativa L. seed extracts obtained by supercritical carbon dioxide. J. Food Sci. Technol. 2010, 47, 598-605. [CrossRef]

30. Sovova, H.; Sajfrtova, M.; Topiar, M. Supercritical $\mathrm{CO}_{2}$ extraction of volatile thymoquinone from Monarda didyma and M. fistulosa herbs. J. Supercrit. Fluids 2015, 105, 29-34. [CrossRef]

31. Goel, S.; Mishra, P. Thymoquinone inhibits biofilm formation and has selective antibacterial activity due to ROS generation. Appl. Microbiol. Biotechnol. 2018, 102, 1955-1967. [CrossRef] [PubMed]

32. Hariharan, P.; Paul-Satyaseela, M.; Gnanamani, A. In vitro profiling of antimethicillin-resistant Staphylococcus aureus activity of thymoquinone against selected type and clinical strains. Lett. Appl. Microbiol. 2016, 62, 283-289. [CrossRef] [PubMed]

33. Kouidhi, B.; Zmantar, T.; Jrah, H.; Souiden, Y.; Chaieb, K.; Mahdouani, K.; Bakhrouf, A. Antibacterial and resistance-modifying activities of thymoquinone against oral pathogens. Ann. Clin. Microbiol. Antimicrob. 2011, 10, 29. [CrossRef] [PubMed] 